\title{
Application of Trickling Filter and Vertical Flow Constructed Wetland Bed to Treat Sewage from Craft Brewery
}

\author{
Wojciech Dąbrowski" ${ }^{*}$, Beata Karolinczak² \\ 1 Bialystok University of Technology, Faculty of Building and Environmental Engineering, ul. Wiejska 45E, \\ 15-351 Białystok, Poland \\ 2 Warsaw University of Technology, Faculty of Building Services Hydro and Environmental Engineering, \\ ul. Nowowiejska 20, 00-653 Warsaw, Poland \\ * Corresponding author's e-mail:w.dabrowski@pb.edu.pl
}

\begin{abstract}
In Poland, as well as worldwide, an increase in craft beer production can be observed. In the last several years, more than 150 of such breweries have appeared and according to Polish Brewery Association, their number might ultimately reach 500. Many of them emerge in the areas with no access to a central sewerage system so they have to solve the problem of waste management on their own. The article presents the results of research on the possibility of using a hybrid system for biological treatment of sewage from craft breweries. The sewage came from a craft brewery Waszczukowe located in the Podlaskie province. A laboratory scale model consisted of a trickling filter (TF) (research model Gunt CE701e) and vertical flow constructed wetland (SS-VF). Innovative filling (Certyd produced by LSA company) of TF and SS VF was applied. The conducted study included determining the changes in the sewage parameters during hybrid treatment, as well as TF and SS VF efficiency separately. The aim of the research was to show the possibility of treating sewage to a point when it was possible to discharge it to a receiver, in compliance with the Polish legal regulations. The research results might be used in designing a treatment system or sewage pretreatment in craft breweries. The average efficiency of TF operating with $100 \%$ recirculation was $76 \%$ for $\mathrm{BOD}_{5}, 80 \%$ for $\mathrm{COD}, 26 \%$ for $\mathrm{TN}$ and $34 \%$ for TP, while the total treatment efficiency of a hybrid system (TF and SS-VF) was $98 \%, 98 \%, 72 \%$ and $77 \%$, respectively. The load of TF during operation with recirculation was on average $0.38 \mathrm{~kg} \mathrm{BOD}_{5} \mathrm{~m}^{-2} \mathrm{~d}^{-1}, 0.57 \mathrm{~kg} \mathrm{COD} \mathrm{m}^{-2} \mathrm{~d}^{-1}$. The load of SS-VF was on average $0.09 \mathrm{~kg} \mathrm{BOD}_{5} \mathrm{~m}^{-2} \mathrm{~d}^{-1}$ and $0.12 \mathrm{~kg} \mathrm{COD} \mathrm{m}^{-2} \mathrm{~d}^{-1}$. The obtained results of hybrid treatment permitted to discharge the sewage to the receiver.
\end{abstract}

Keywords: craft brewery, sewage treatment, trickling filter, vertical flow constructed wetland, Certyd

\section{INTRODUCTION}

Beer revolution is a term strictly connected with the development of small breweries in Poland since 2011. Small breweries include microbreweries, restaurant and contract breweries. The number of small breweries grew from 29 to 200 between the years 2011 and 2016 [Wojtyra \& Grudzień 2017]. Ultimately, around 5000 craft breweries might appear on the Polish market; their share in beer production is currently at around $0.5 \%$. For comparison, there are around 1000 such breweries in Germany and almost 5000 in the United States.
For the craft breweries located in non-urbanized areas, sewage treatment is a significant problem. If there is no possibility of discharging sewage to a central sewerage system or if the WWTP is insufficient, it is necessary to build a system for sewage treatment or pretreatment. The sewage treatment technology for a craft brewery should be adjusted to the changing pollutant loads connected with this specific type of production. The craft brewery sewage is characterized by higher pollutants indicators in comparison with large industrial facilities; also, the irregularity of its discharge is larger [Janczukowicz et al. 2013]. This type of sewage can be treated with physical, 
chemical as well as biological methods. The treatment of brewery sewage for reuse requires an application of membrane filtration after the biological stage [Simate et al. 2011].

In the case of manufacture breweries, the most common solution is anaerobic sewage pretreatment before discharge to a municipal WWTP. The anaerobic sewage treatment in beer production has a number of advantages, including the possibility of producing electric energy from the biogas generated in the process of anaerobic sewage treatment. Manufacture breweries typically have access to a sewerage system and municipal WWTPs and can discharge their pretreated sewage there. A full treatment process after which the sewage reaches the parameters that allow its discharge to receivers is also possible [Simate et al. 2011, Driessen \& Vereijken 2003, Enitan et al. 2014]. This solution is the most beneficial one from the point of view of WWTPs. Brewery sewage has a similar composition to that of municipal sewage; however, it is characterized by a much higher content of organic substances measured by $\mathrm{BOD}_{5}$ and COD indicators. It is possible to apply classical sludge aeration chambers, but unlike anaerobic treatment, it is necessary to supply energy for aeration process. Trickling filters (TF) are not popular for brewery sewage treatment. With rotary biological contactors, they are mainly applied for domestic or municipal sewage treatment [SzulżykCieplak et al. 2018]. Their efficiency is lower in comparison with a sludge activated system, especially for the nitrogen and phosphorus removal. An additional treatment may be required to obtain the discharge standards. On the other hand, they have many advantages such as no excess sludge, low power requirements and effectiveness in treating high concentration of organics [Daigger \& Boltz 2011, Post \& Medlock 2002, Żyłka et al. 2018].

Constructed wetlands have been used for the treatment of municipal and industrial sewage, septage, reject water, rain water or landfill leachate [Dąbrowski et al. 2018, 2019, Kadlec and Wallace 2009, Karolinczak and Dąbrowski 2017, Kołecka et al. 2017, Puchlik 2016]. Such systems are considered as an environmentally friendly and low-cost technology. No chemicals are added and there is no need for artificial aeration. Kadlec (2009) reported the application of $\mathrm{CW}$ systems for food processing sewage in the following areas: sugar refining, potato processing, milk products, meat processing as well as dairy, pig and cattle farms. Additionally, winery effluent can be treated with different types of CWs. On the other hand, only a few applications of CWs can be found for treatment of brewery sewage. The South African Miller brewery plant tested a system of anaerobic treatment with integrated algae pond with final treatment using a horizontal flow CW system [Massi et al. 2018]. Kadlec and Wallace (2009) reported a Free Water Surface (FWS) to be in operation for the Coors Brewery in Colorado, USA.

Due to the low daily amount of sewage discharged from craft breweries there are no grounds to apply the anaerobic system. The biological treatment systems based on active sludge require a constant sewage feed; it is also necessary to solve the problem of sewage sludge treatment. The trickling filter technology ensures high efficiency treatment without typical waste (excess sludge) generated during sludge activated treatment process. There is no need for the artificial aeration and power requirement is low.

The authors suggest applying a hybrid system based on a TF and SS-VF constructed wetland. A similar solution based on a TF system and final treatment in two stages SS VF for domestic wastewater treatment was developed by the French company SCRIPE [Gourdon et al. 2017].

The research conducted in laboratory scale with the real sewage from a craft brewery will allow designing an implementation installation which ultimately can be used in Waszczukowe brewery in case of significant production increase.

\section{MATERIAL AND METHODS}

\section{Laboratory scale research installation}

The hybrid research installation consisted of a TF and SS VF was operating in a laboratory at Department of Environmental Engineering Technology and Systems, BUT. A scheme of the research installation and sampling points are presented in Figure 1.

The TF was designed by GUNT company (Figure 2). The total volume of the TF was 90 liters, while the surface area amounted to 0.09 $\mathrm{m}^{2}$. The retention tank had the volume of $200 \mathrm{li}$ ters. A rotary distributor allowed supply of the bed, whereas the aeration vents below a fixed bed supplied the biofilm process with oxygen. CE 701 model is equipped with a collecting tank and recirculation pumps. A secondary clarifier and 


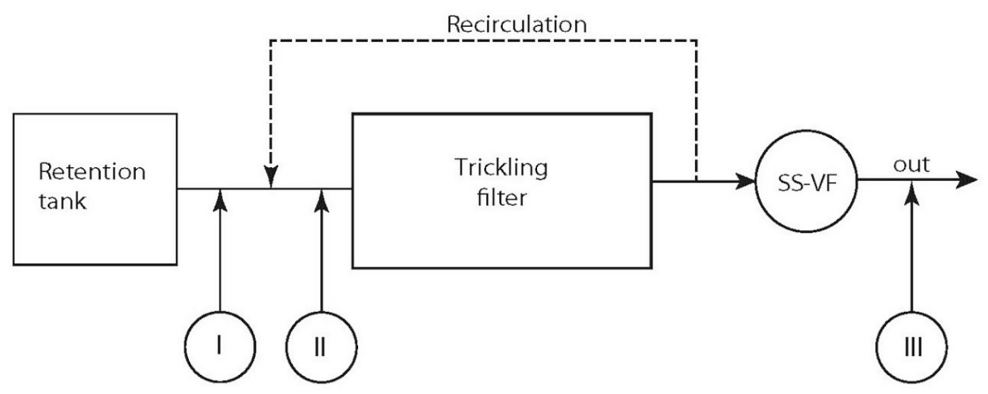

Fig. 1. Scheme of hybrid research installation with sampling points

aeration compressor were used during the startup of the biofilm process with domestic sewage.

In order to avoid clogging, an innovative filling was applied in the TF as additional to plastics (Figure 2). It was lightweight sintered aggregate (LSA) Certyd. It is a ceramic and porous material produced in accordance with LSA technology featuring sintering process in a rotary furnace. It is obtained by thermal processing of ash. The product is confirmed with EN-13055:2016-07 Light aggregate standard. It has the certificate of National Institute of Hygiene no. HR/B/86/2015 [LSA LLC]. The main filling of the TF was plastic $(80 \%)$ and Certyd (20\%).

The startup was carried out for a few weeks, until stable parameters of domestic sewage were obtained. The examination of the biofilm structure ensured the proper functioning of the bed. After the start up process, the installation started to treat the brewery sewage. The TF was operating with $100 \%$ recirculation, the hydraulic load was $0.3 \mathrm{~m}^{3} \mathrm{~m}^{-2} \mathrm{~d}^{-1}$.

SS VF was the second part of the hybrid system. Figure 3 presents a cross section of SS VF bed. The surface of SS VF was $0.1 \mathrm{~m}^{2}$, its height $0.8 \mathrm{~m}$. The bed was planted with Phragmites australis. It was filled only with Certyd, which was tested as a material substituting natural filling e.g. sand and gravel. In the last decade, research was conducted several times applying different materials as filter media in trickling filters and constructed wetlands [Dąbrowski et al. 2018, Ali et al. 2017, Ashan et al. 2017, Łobos-Moysa et al. 2016, Habte Lemji \& Eckstädt 2013]. The hydraulic load of the SS VF bed supplied with brewery sewage treated in the TF was $0.1 \mathrm{~m}^{3} \mathrm{~m}^{-2} \mathrm{~d}^{-1}$. The SS-VF bed was operating as classical one stage unsaturated system [Nivala et al. 2019, Karolinczak \& Dąbrowski 2017].

\section{Sampling and scope of the determination}

The efficiency tests of the hybrid system were carried out from February to May 2019 (ten series after the start-up process). The parameters of installation operation were determined on the basis of quality tests of sewage from a craft brewery from 2018. The raw brewery sewage used in laboratory tests was sampled from an averaging tank installed in the brewery and transported to the BUT laboratory. The air temperature during the laboratory scale experiment was stable and varied from

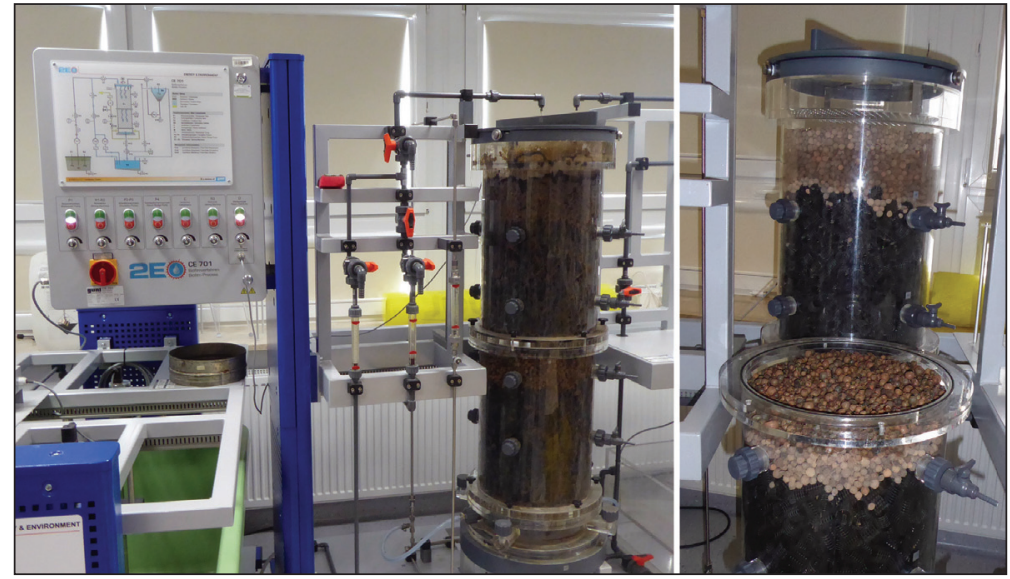

Fig. 2. Trickling filter during operation. View of the filling material: plastic and Certyd. 


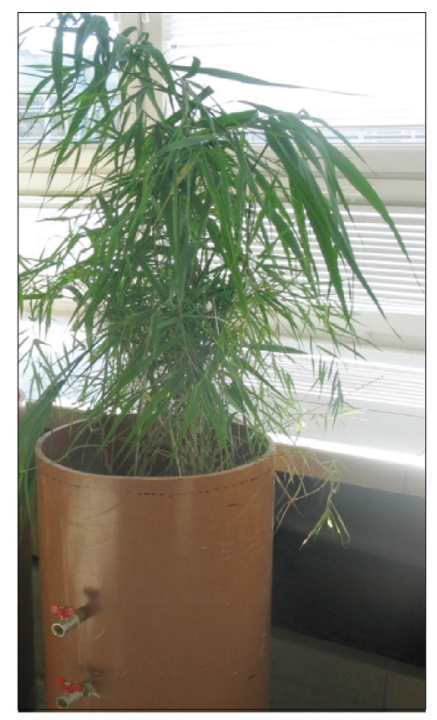

$$
\begin{array}{ll}
\text { I-Certyd } & 0-2 \mathrm{~mm} \quad(0,10 \mathrm{~m}) \\
\text { II-Certyd } & 1-4 \mathrm{~mm}(0,50 \mathrm{~m}) \\
\text { III-Certyd } & 4-9 \mathrm{~mm}(0,20 \mathrm{~m})
\end{array}
$$

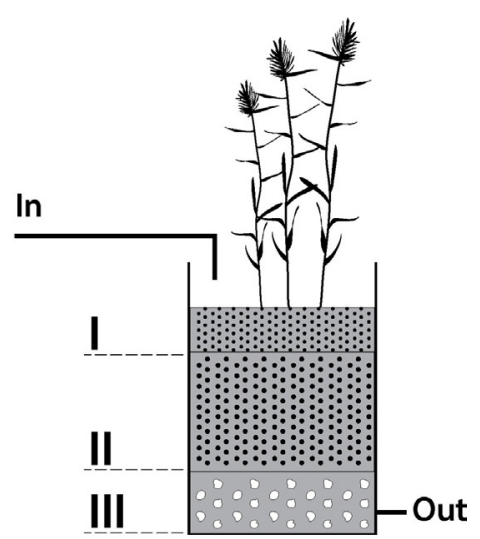

Fig. 3. Laboratory scale constructed wetland SS-VF used during experiment

$18^{\circ} \mathrm{C}$ to $20^{\circ} \mathrm{C}$. The basic analyses were performed: biochemical oxygen demand $\mathrm{BOD}_{5}$, chemical oxygen demand COD, total Kjeldahl nitrogen TKN, ammonia nitrogen $\mathrm{N}^{-\mathrm{NH}_{4}^{+}}$, nitrate nitrogen (V) $\mathrm{N}^{-\mathrm{NO}_{3}^{-}}$, nitrite nitrogen (III) $\mathrm{N}_{-} \mathrm{NO}_{2}^{-}$and total phosphorus TP. Also, $\mathrm{pH}$, conductivity and dissolved oxygen concentration were monitored to check the technological parameters of the TF and SS VF bed.

The tests were conducted in BUT laboratory in accordance with the procedures set out in the Regulation of the Environmental Protection Minister from $18^{\text {th }}$ November 2014 and in accordance with the American Public Health Association [Regulations 2014, APHA 2005]. The parameters of brewery sewage (with $100 \%$ recirculation) as sewage after treatment with the TF supplying a SS VF bed were used to calculate the pollutants load. The removal efficiency was calculated as a concentration reduction in hybrid system and separately for the TF and SS VF bed. Additionally, the parameters of raw brewery sewage without recirculation were determined. All sampling points (I-IV) were presented in Figure 1.

\section{RESULTS AND DISCUSSION}

\section{Characteristics of craft brewery sewage}

The main parameters of raw sewage from Waszczukowe craft brewery company are presented in Table 1. The samples were taken from an averaging tank located within the company.

The parameters of raw sewage are mainly connected with the washing process [Janczukowicz et al. 2013]. In large brewery companies, cleaning-in-place stations (CIP) are commonly in use. In small breweries, the process of washing is managed without CIP installations. In addition, the water and sewage management in a craft brewery is different in comparison with large companies. It concerns cooling water especially. The parameters presented in Table 1 are mostly similar to those achieved by different authors analyzing brewery sewage characteristics and its treatment [Driessen \& Vereijeken 2003, Simate et al. 2011, Enitan et al. 2014, Janczukowicz et al. 2013]. The composition of brewery sewage is similar to the parameters of sewage from e.g.

Table 1. Characteristics of raw sewage from craft brewery plant - sampling point I

\begin{tabular}{|c|c|c|c|}
\hline Parameter & Unit & Mean \pm st. dev. & Min-max \\
\hline $\mathrm{BOD}_{5}$ & $\mathrm{mg} \mathrm{O}_{2} \mathrm{dm}^{-3}$ & $2140 \pm 143$ & $1940-2360$ \\
\hline $\mathrm{COD}$ & $\mathrm{mg} \mathrm{O}_{2} \mathrm{dm}^{-3}$ & $3910 \pm 197$ & $3600-4200$ \\
\hline $\mathrm{TKN}$ & $\mathrm{mg} \mathrm{N} \mathrm{dm}^{-3}$ & $42.0 \pm 5.0$ & $36.0-51.0$ \\
\hline $\mathrm{NH}_{4}^{+}-\mathrm{N}$ & $\mathrm{mg} \mathrm{NH}_{4}{ }^{+}-\mathrm{N} \mathrm{dm}^{-3}$ & $5.6 \pm 1.5$ & $3.6-8.9$ \\
\hline $\mathrm{NO}_{3}^{-}-\mathrm{N}$ & $\mathrm{mg} \mathrm{NO}_{3}^{-}-\mathrm{N} \mathrm{dm}^{-3}$ & $1.7 \pm 0.5$ & $1.0-2.6$ \\
\hline $\mathrm{TN}$ & $\mathrm{mg} \mathrm{N} \mathrm{dm}^{-3}$ & $43.8 \pm 5.2$ & $37.2-52.0$ \\
\hline $\mathrm{TP}$ & $\mathrm{mg} \mathrm{P} \mathrm{dm}^{-3}$ & $23.6 \pm 2.5$ & $19.8-28.0$ \\
\hline
\end{tabular}


dairy or meat industry [Żyłka et al. 2018]. It is characterized by high content of organic substances measured by $\mathrm{BOD}_{5}$ and COD. While analyzing biogenic compounds, it was concluded that the total nitrogen concentration is lower than in municipal sewage, while the phosphorous concentration is higher [Heidrich \& Witkowski 2015, Klimiuk \& Łebkowska 2004]. The phosphorous contained in brewery sewage comes from the processes of washing machines. The concentration of biogenic compounds is strictly connected with how machines are washed. In the analyzed brewery an automatic cleaning station Cleaning in Place (CIP) is not used, which might affect the higher concentration of ammonia nitrogen and phosphorus. During the research, it was observed that ammonia in the $\mathrm{N}-\mathrm{NO}_{2}$ form practically does not occur in both raw and treated brewery sewage.

\section{Treatment efficiency}

Table 2 presents the results of tests on the sewage which was fed to the trickling filter (sampling point II, Fig. 1), inlet to SS-VF (sampling point III, Fig. 1) and the outflow from hybrid system (sampling point IV, Fig. 1). The applied recirculation level resulted from the necessity of reducing the pollutants load in the sewage which supplied the SS-VF bed so that upon reaching the outflow the sewage had parameters compliant with legal regulations [Regulation 2014].

Applying 100\% recirculation during the TF operation decreased the parameters of raw sewage to $1256 \mathrm{mgO}_{2} \mathrm{dm}^{-3}$ for $\mathrm{BOD}_{5}$ and $1891 \mathrm{mgO}_{2} \mathrm{dm}^{-3}$ for $\mathrm{COD}$, respectively. It enabled to increase the process effectiveness through reaching the parameters similar to those of municipal sewage. The concentration of total ammonia after the treatment process with the use of TF varied between from 20.0 to $28.9 \mathrm{mgN} \mathrm{dm}^{-3}$ and from 9.5 to $13.1 \mathrm{mg} \mathrm{P} \mathrm{dm}^{-3}$ for phosphorus, respectively.
Figure 4 presents the efficiency of brewery sewage treatment in research installation: separately for trickling filter $\mathrm{TF}$, constructed wetland SS VF and total efficiency of the hybrid system. The effectiveness was calculated on the basis of average parameter values of sewage supplying particular installation elements.

The obtained results confirm the possibility of highly efficient treatment of all parts of the hybrid system. The trickling filter was operating low-loaded with the average load of $0.376 \mathrm{~kg} \mathrm{BOD} \mathrm{m}^{-3} \mathrm{~d}^{-1}$.

Low hydraulic load resulted from the fact that the sewage, which supplied the bed was characterized by the high content of organic substance in comparison with typical municipal sewage for which the trickling filter operating parameters were established [Daigger \& Boltz 2011, Ali et al. 2017]. The average pollutant load of SS VF was $90.9 \mathrm{gO}_{2} \mathrm{~m}^{-2} \mathrm{~d}^{-1}$ for $\mathrm{BOD}_{5}$ and $115.2 \mathrm{gO}_{2} \mathrm{~m}^{-2} \mathrm{~d}^{-1}$ for COD. Low hydraulic load allowed s successful removal of organic substances. The effectiveness of the hybrid system was high and reached $98 \%$ for $\mathrm{BOD}_{5}$ and $\mathrm{COD}, 72 \%$ for $\mathrm{TN}$ and $77 \%$ for TP. It confirmed the purpose of applying the hybrid system. Gourdon et al. (2017) conducted a similar research on the intensification of removing ammonia and phosphorous in a hybrid system consisting of a trickling filter (for biological pretreatment) followed by two stages of partially saturated vertical flow beds planted with reeds. The removal efficiency of domestic sewage in SS VF beds was on average $97.9 \%$ for $\mathrm{BOD}_{5}, 94 \%$ for $\mathrm{COD}, 70.9 \%$ for $\mathrm{TN}$ and $59.6 \%$ for $\mathrm{TP}$.

\section{CONCLUSIONS}

A growing market of craft breweries in Poland causes the necessity of sewage treatment or pretreatment with the use of a simple, effective

Table 2. Characteristics of inflow to biological filter (sampling point II) and inflow (III) and outflow (IV) from SS VF

\begin{tabular}{|c|c|c|c|c|c|c|c|}
\hline \multirow{2}{*}{\multicolumn{2}{|c|}{$\begin{array}{c}\text { Parameter } \\
\text { Unit }\end{array}$}} & \multicolumn{2}{|c|}{ Inflow to TF } & \multicolumn{2}{|c|}{$\begin{array}{l}\text { Outflow from TF } \\
\text { Inflow to SS VF }\end{array}$} & \multicolumn{2}{|c|}{ Outflow from SS VF } \\
\hline & & \multirow{2}{*}{$\begin{array}{c}\begin{array}{c}\text { Mean } \\
\pm \text { st.dev. }\end{array} \\
1256 \pm 120\end{array}$} & \multirow{2}{*}{$\begin{array}{c}\text { Min-max } \\
980-1440\end{array}$} & \multirow{2}{*}{$\begin{array}{c}\text { Mean } \\
\pm \text { st.dev. }\end{array}$} & \multirow{2}{*}{$\begin{array}{l}\text { Min-max } \\
270-330 \\
\end{array}$} & \multirow{2}{*}{$\begin{array}{c}\begin{array}{c}\text { Mean } \pm \text { st. } \\
\text { dev. }\end{array} \\
21 \pm 2\end{array}$} & \multirow{2}{*}{$\frac{\text { Min-max }}{18-24}$} \\
\hline $\mathrm{BOD}_{5}$ & $\mathrm{mgO}_{2} \mathrm{dm}^{-3}$ & & & & & & \\
\hline COD & $\mathrm{mgO}_{2} \mathrm{dm}^{-3}$ & $1891 \pm 106$ & 1730-2060 & $384 \pm 24$ & $350-430$ & $40 \pm 3$ & $32-43$ \\
\hline TNK & $\mathrm{mgN} \mathrm{dm}^{-3}$ & $31.7 \pm 4.1$ & $26.2-41.0$ & $17.4 \pm 2.1$ & $14.0-22.0$ & $5.5 \pm 0.5$ & $5.0-6.2$ \\
\hline $\mathrm{NH}_{4}^{+}-\mathrm{N}$ & $\mathrm{mgN}-\mathrm{NH}_{4}{ }^{+} \mathrm{dm}^{-3}$ & $2.8 \pm 0.7$ & $2.0-4.0$ & $0.4 \pm 0.2$ & $0.2-0.6$ & $0.1 \pm 0.1$ & $0.0-0.3$ \\
\hline $\mathrm{NO}_{3}-\mathrm{N}$ & $\mathrm{mgN}-\mathrm{NO}_{3}-\mathrm{dm}^{-3}$ & $1.1 \pm 0.2$ & $0.8-1.6$ & $6.9 \pm 0.9$ & $6.0-9.0$ & $3.7 \pm 0.4$ & $3.0-4.2$ \\
\hline $\mathrm{TN}$ & $\mathrm{mgN} \mathrm{dm}^{-3}$ & $32.8 \pm 4.1$ & $27.1-41.8$ & $24.3 \pm 2.4$ & $20.0-28.9$ & $9.3 \pm 0.5$ & $8.2-10.2$ \\
\hline TP & $\mathrm{mgP} \mathrm{dm}^{-3}$ & $17.2 \pm 1.2$ & $16.0-20.1$ & $11.3 \pm 1.1$ & $9.5-13.1$ & $3.9 \pm 0.5$ & $2.9-4.7$ \\
\hline
\end{tabular}




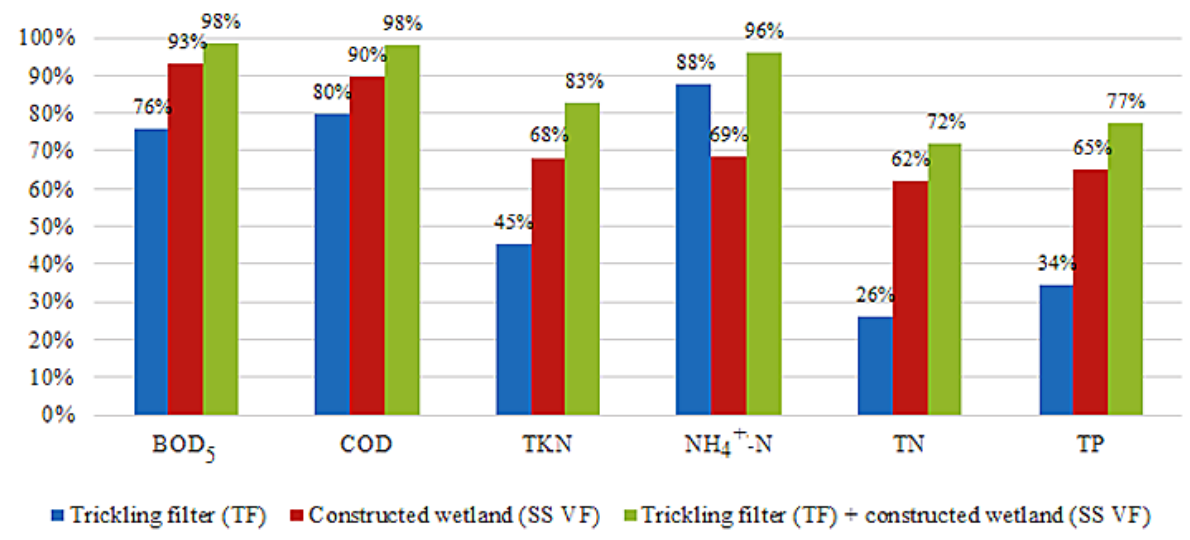

Fig. 4. Efficiency of TF, SS-VF and hybrid system

and tested technology. Diverse demands in terms of sewage treatment degree require hybrid technology which will allow, depending on the needs, full treatment or pretreatment of sewage. In the case of pretreatment of the sewage discharged to municipal WWTPs, it is possible to construct and exploit a chosen element of the hybrid system.

The results from this study confirm the high efficiency of craft brewery sewage treatment in hybrid systems consisting of TF and SS-VF. The total efficiency of organic substances removal measured by $\mathrm{BOD}_{5}$ was on average $98 \%$ for hybrid while $76 \%$ for TF and $93 \%$ for SS-VF. The TN removal was $72 \%, 26 \%$ and $62 \%$ respectively, while TP $77 \%, 34 \%$ and $65 \%$.

Moreover, the research has proven the possibility of applying the Certyd filling, obtained from waste, as filter media in the TF and SS VF bed. It was confirmed by the tests on biofilm biocoenosis during the system start-up and exploitation.

The conclusions from the research can be used for a real-scale application project. The possibility of sewage recirculation in SS-VF bed for higher efficiency treatment will also be anticipated in the implementation system. Further studies will explore the possibility of water reuse in the craft brewery industry.

\section{Acknowledgements}

The study was conducted as a research project Z/WBiIS/8/2019 in Faculty of Civil and Environmental Engineering of Bialystok University of Technology, financed by Ministry of Science and Higher Education of Poland.

The authors thank the owners of the Waszczukowe brewery for cooperation during the research.

\section{REFERENCES}

1. Ali I., Khan Z.M., Peng C., Nazz I., Niaz Y., Sultan. M. 2017. Identification and Elucidation of the Designing and Operational Issues of Trickling Filter Systems for Wastewater Treatment, Pol. J. Environ. Studies, 26(6), 2431-2444.

2. American Public Health Association (APHA) 2005. Standard Methods for Examination of Water and Wastewater. 21st edition. American Public Health Association. Washington.

3. Ashan M., Khan Z.M., Sultan M., Niaz Y., Mamhood M., Shoaib M., Shakoor A., Ahmad M. 2017. Performance Evaluation of Trickling Filter-Based Wastewater \treatment Isystems Utilizing Cotton Sticks as Filter Media, Pol. J. Environ. Studies, 26(5), 1955-1962.

Table 3. TF and SS-VF load and load removed

\begin{tabular}{|c|c|c|c|c|}
\hline \multirow{2}{*}{ Parameter } & \multicolumn{2}{|c|}{ Load } & \multicolumn{2}{c|}{ Load removed } \\
\cline { 2 - 5 } & TF & SS-VF & TF & $\mathrm{g} \mathrm{m}^{-2} \mathrm{~d}^{-1}$ \\
\hline & $\mathrm{g} \mathrm{m}^{-2} \mathrm{~d}^{-1}$ & $\mathrm{~g} \mathrm{~m}^{-2} \mathrm{~d}^{-1}$ & $285.9 \pm 31.9$ & $88.9 \pm 5.7$ \\
\hline $\mathrm{BOD}_{5}$ & $376.8 \pm 35.9$ & $90.9 \pm 5.9$ & $452.1 \pm 27.0$ & $111.2 \pm 7.0$ \\
\hline $\mathrm{COD}$ & $567.3 \pm 31.8$ & $115.2 \pm 7.1$ & $4.3 \pm 0.6$ & $4.7 \pm 0.6$ \\
\hline $\mathrm{TNK}$ & $9.5 \pm 1.2$ & $5.2 \pm 0.6$ & $0.7 \pm 0.2$ & $0.1 \pm 0.04$ \\
\hline $\mathrm{NH}_{4}{ }^{+}-\mathrm{N}$ & $0.9 \pm 0.2$ & $0.1 \pm 0.05$ & $2.6 \pm 0.7$ & $6.4 \pm 0.7$ \\
\hline $\mathrm{TN}$ & $9.8 \pm 1.2$ & $7.3 \pm 0.7$ & $1.8 \pm 0.4$ & $3.0 \pm 0.3$ \\
\hline $\mathrm{TP}$ & $5.2 \pm 0.4$ & $3.4 \pm 0.3$ & & \\
\hline
\end{tabular}


4. Daigger G.T., Boltz J.P., 2011. Trickling Filter and Trickling Filter-Suspended Growth Process Design and Operation: A state of art - Revive. Water Environmental Research, 83(5), 388-404. DOI 10.2175 /106143010X1268105917210.

5. Dąbrowski W., Karolinczak B., Malinowski P. 2018. Application of SS-VF Bed for the Treatment of High Concentrated Reject Water from Autothermal Termophilic Aerobic Sewage Sludge Digestion, 19(4), 103-110. https://doi.org/10.12911/22998993/89663.

6. Dąbrowski W., Karolinczak B., Malinowski P. 2019. Modeling of Pollutants Removal in Subsurface Vertical Flow and Horizontal Flow Constructed Wetlands, Water 11(1), 180, DOI: 10.3390/ w11010180.

7. Driessen W., Vereijken T. 2003. Recent developments in biological treatment of brewery effluent, The Institute and Guild Brewing Convention, Livingstone, Zambia.

8. Enitan A. M., Swalaha F. M, Adeyemo J., Bux F. 2014. Assessement of Brewery Effluent Compostion from beer producing industry in KwazuluNatal, South Africa, Fresenius Environmental Bulletin, 23(3), 693-701.

9. Gourdon R., Kania M., Gautier M., Kim B., Michel P. 2017. Treatment of domestic wastewater from small cities on vertical flow constructed wetlands (VFCWs), Springer, CIGOS Vietnam.

10. Habte Lemji H., Eckstädt H. 2013. A pilot scale trickling filter with pebble gravel as media and its performance to remove chemical oxygen demand from synthetic brewery wastewater, Journal of Zhejiang University-SCIENCE B (Biomedicine \& Biotechnology), 14, 10, 924-933.

11. Heidrich Z., Witkowski A. 2015. Urzadzenia do oczyszczania ścieków projektowanie przykłady obliczeń. Wydawnictwo „Seidel-Przywecki” Sp. z o.o., Warszawa.

12. Kadlec R. H., Wallace S. D. 2009. Treatment Wetlands, 2nd ed. CRC Press: Boca Raton, FL, USA

13. Karolinczak B., Dąbrowski W. 2017. Effectiveness of septage pre-treatment in subsurface vertical flow constructed wetlands, Water Sci. Technol. 76(9), 2544-2553, DOI: 10.2166/wst.2017.398.

14. Klimiuk E., Lebkowska M. 2004. Biotechnologia w ochronie środowiska. Wydawnictwo Naukowe PWN, Warszawa.

15. Kołecka K, Gajewska M., Obarska-Pempkowiak H., Rohde D. 2017 Integrated dewatering and stabilization system as an environmentally friendly technology in sewage sludge management in Poland. Inżynieria Ekologiczna, 98, 346-353.

16. Łobos-Moysa E., Bodzek M., Śliwa A. 2016,
Wpływ modyfikacji kruszyw porowatych na efektywność oczyszczania ścieków na złożach biologicznych, Proceedings of ECOpole, 10, 2, 693-698, DOI 10.2429/proc2016.10(1)076.

17. Massi F., Rizzo A., Bresciani R. 2018. Treatment of Wineries and Breweries Effluents Using Constructed Wetlands, Constructed Wetlands for Industrial Wastewater Treatment, First Edition Edit. Stefanakis A., John Willey \& Sons Ltd., 96-104.

18. Nivala N., Afferden M., Hasselbach R., Langergraber G., Molle P., Rustige H., Nowak J. 2019. The new German standard on constructed wetland systems of domestic and municipal wastewater. Water Science \& Technology, DOI 10.2166/wst.2018.530.

19. Post T., Medlock J. 2002 Wastewater Technology Fact Sheet Trickling filters, U.S Environmental Protection Agency, Office of Water Washington D.C. EPA 832-F00-014.

20. Puchlik M. 2016. Application of constructed wetlands for treatment of wastewater from fruit and vegetable industry, J. Ecol. Eng. 17(1), 131-135, DOI: $10.12911 / 22998993 / 61201$.

21. Regulations of the Minister of Environment from 18th of November 2014 on conditions to be met for disposal of treated sewage into water and soil and concerning substances harmful to the environment (Dz.U. 2014. no. 1800).

22. Janczukowicz W., Rodziewicz J., Mielcarek A., Filipkowska U., Kłodowska I., Ostrowska K., Jóżwiak T., Kordas M. 2013. Quality Characteristics of Wastewater from Malt and Beer Production. Annual Set of Environmental Protection, 15, 729-748.

23. Simate G., Cluett J., Iyuke E., Musaptika E.T., Ndlovu S., Walubita F., Alvarez A.E. 2011. The treatment of brewery wastewater for reuse: State of the Art, Desalination, 273, 235-247, DOI 10.1016/j. desal.2011.02.035.

24. Szulżyk-Cieplak J., Tarnogórska A., Lenik Z. 2018. Study on the Influence of Selected Technological Parameters of a Rotating Biological Contactor on the Degree of Liquid Aeration. J.Ecol.Eng. 19(6), 247253. https://doi.org/10.12911/22998993/92512.

25. Wojtyra B., Grudzień Ł. 2017. The Development of the Beer Industry in Poland During "The Craft Beer Revolution" (2011-2016). Studies of the Industrial Geography Commission of the Polish Geographical Society. 31(*1). DOI 10.24917/20801653.311.4.

26. Żyłka R., Dąbrowski W., Gogina E., Yancen O. 2018. Trickling Filter for High Efficiency Treatment of Dairy Sewage, J. Ecol. Eng. 19(4), 269275, https://doi.org/10.12911/22998993/89657. 